\title{
Characterization of proteins secreted from a Type III secretion system of Edwardsiella tarda and their roles in macrophage infection
}

\author{
Jun Okuda ${ }^{1,4}{ }^{, *}$, Makoto Kiriyama ${ }^{1}$, Etsuko Suzaki ${ }^{2}$, Katsuko Kataoka ${ }^{2}$, \\ Mitsuaki Nishibuchi ${ }^{3}$, Toshihiro Nakai ${ }^{1}$ \\ ${ }^{1}$ Graduate School of Biosphere Science, Hiroshima University, 1-4-4, Kagamiyama, Higashi-Hiroshima 739-8528, Japan \\ ${ }^{2}$ Graduate School of Biomedical Science, Hiroshima University, Kasumi 1-2-3, Minami-ku, Hiroshima 734-8551, Japan \\ ${ }^{3}$ Centre for Southeast Asian Studies, Kyoto University, Kyoto 606-8501, Japan \\ ${ }^{4}$ Present address: Department of Microbiology and Infection Control Science, Kyoto Pharmaceutical University, \\ Yamashina-ku, Kyoto 607-8414, Japan
}

\begin{abstract}
The Type III secretion system is essential for intracellular replication of Edwardsiella tarda in phagocytes of fish and mammals. We identified the secreted proteins of the Type III secretion system by comparing the wild-type strain and the Type III mutant mET1229. The wild-type strain secreted 55, 25, and $22 \mathrm{kDa}$ proteins into the culture supernatant, whereas the Type III mutant did not. These proteins were identified as EseB, EseC, and EseD and are similar in sequence to Salmonella SseB, SseC, and SseD that function as a translocon. The EseB, EseC, and EseD knockout mutants did not replicate in murine macrophages, suggesting that these proteins are essential for intracellular replication of E. tarda. Highest secretion of EseBCD proteins was observed when bacterial cells were cultured in neutral and alkaline $\mathrm{pHs}$ but not in acidic $\mathrm{pH}$. When the $\mathrm{pH}$ of the phagosomes was examined using an acidotropic probe, the phagosomes containing the wild-type strain showed neutral $\mathrm{pH}$, whereas those containing the Type III mutant exhibited acidic $\mathrm{pH}$. These results suggest that the Type III-dependent interference with formation of the acidic environment in phagosomes is essential for intracellular replication of bacteria in murine macrophages.
\end{abstract}

KEY WORDS: Edwardsiella tarda $\cdot$ EseBCD proteins $\cdot$ Translocon $\cdot$ Phagosomal pH $\cdot$ Macrophage

\section{INTRODUCTION}

Edwardsiellosis is a serious disease problem in many cultured freshwater and seawater fishes worldwide (Plumb 1999, Muroga, 2001). The causative agent of the disease, Edwardsiella tarda, has been isolated from a wide variety of animals, including mammals and humans (Sakazaki 2001). In Japan, E. tarda has been known to be an important pathogen, particularly in Japanese eel Anguilla japonica, Japanese flounder Paralichthys olivaceus and red sea bream Pagrus major cultures, since the 1970s. Although persistent studies have been performed on the disease and the agent, there is no efficacious control method for this chronic disease due to poor understanding of the infection mechanism in addition to lack of effective chemotherapy. A number of virulence factors of $E$. tarda have been reported, including the ability to invade epithelial cells (Janda et al. 1993), to resist phagocyte-mediated killing (Ainsworth \& Chen 1990, Iida \& Wakabayashi 1993), and to produce toxins such as dermatotoxins (Ullah \& Arai 1983) and haemolysins (Hirono et al. 1997, Strauss et al. 1997). Among these virulence factors, the ability to resist phagocyte-mediated killing by failing to trigger the respiratory burst gives it a niche advantage in the host (Srinivasa Rao et al. 2001). In addition, we have recently reported that the anti-apoptotic effect of its infection in murine 
macrophages is important for efficient intracellular growth of bacteria in the macrophages (Okuda et al. 2006). However, only scant information is available on the pathogenicity of E. tarda.

Many gram-negative pathogenic bacteria use a conserved protein secretion machinery termed 'Type III secretion system' (TTSS) to transport virulence factors and cause disease. The TTSS apparatus consists of approximately 20 to 25 proteins. The unique feature of the TTSS is a needle-like structure through which particular proteins (termed 'effectors') are injected into host cells. Effectors play an important role in the pathogenic relationship between host and bacterium. Injection of effectors into host cells occurs through pores (termed 'translocons)' formed in the host cell membrane by the TTSS using Type III-secreted proteins (Ghosh 2004). The TTSS encoded within Salmonella pathogenicity island 2 (SPI2) is essential for its intracellular accumulation in macrophages. SseB, SseC, and SseD proteins secreted from the TTSS encoded within SPI2 are reported to function as translocons (Nikolaus et al. 2001). Using TnphoA transposon tagging and the proteomics approach, a TTSS was found in Edwardsiella tarda that was similar to that encoded within SPI2 of Salmonella (Srinivasa Rao et al. 2003, Tan et al. 2005). Three TTSS proteins of E. tarda, homologous to SseBCD were identified and these proteins were designated as EseB, EseC, and EseD (Srinivasa Rao et al. 2004, Tan et al. 2005). We reported that, similar to Salmonella, the TTSS encoded within E. tarda is required for its intracellular accumulation in murine macrophages(Okuda et al. 2006). This suggests that the function of the TTSS of E. tarda is to deliver effectors into macrophages using EseBCD proteins as translocons in order to survive in the host cells.

Here we investigate the role of the EseBCD proteins in intracellular replication of the bacterium in murine macrophages by investigating the requirements for the secretion of these proteins.

\section{MATERIALS AND METHODS}

Bacterial strains, bacterial growth, and media. The wild-type strain, Edwardsiella tarda FK1051, was isolated from a diseased Japanese flounder, Paralichthys olivaceus. The Type III mutant mET1229 is a TTSSdeficient mutant of E. tarda FK1051, i.e. the esa $V$ gene in FK1051 was knocked out, as described previously (Okuda et al. 2006).
Insertion mutation was carried out in the ese $B$, ese $C$, and ese $D$ genes in the wild-type strain as described previously (Tan et al. 2005) with a slight modification using the suicide vector plasmid, pRE112 (Okuda et al. 2001). Internal fragments of each gene were amplified by PCR using the primers listed in Table 1, i.e. a $236 \mathrm{bp}$ fragment from position 89 to 324 in the ese $B$ gene (accession number: AY643478), a 501 bp fragment from position 224 to 724 in the eseC gene (AY643478), and a $237 \mathrm{bp}$ fragment from position 103 to 339 in the eseD gene (AY643478) were amplified using $\Delta$ eseB-1 and $\Delta e s e B-2$ primers, $\Delta e s e C-1$ and $\Delta e s e C-2$ primers, and $\Delta e s e D-1$ and $\Delta e s e D-2$ primers, respectively (Table 1). The primers were designed where the amplicon has a SacI site and stop codons at the $5^{\prime}$ end and a SacI site at the 3 ' end. The PCR amplification was performed using Taq polymerase (Ex Taq, Takara) at 30 cycles: $30 \mathrm{~s}$ denaturation at $95^{\circ} \mathrm{C}, 1 \mathrm{~min}$ annealing at $60^{\circ} \mathrm{C}$, an extension step at $72^{\circ} \mathrm{C}$ for $1.5 \mathrm{~min}$, and then a final extension step at $72^{\circ} \mathrm{C}$ for $5 \mathrm{~min}$. The amplified fragments were digested using $S a c I$ and cloned into SacI-cleaved pRE112. The plasmids (designated as $\mathrm{p} \Delta e s e B, \mathrm{p} \Delta e s e C$, and $\mathrm{p} \Delta e s e D$ ) were first constructed using an Escherichia coli SY327 $\lambda$ pir background and $E$. coli SM10 $\lambda$ pir was transformed with them. These plasmids were mobilized into Edwardsiella tarda FK1051 using conjugation. Transconjugants were selected on Trypto-Soya agar (TSA, Nissui) supplemented with chloramphenicol $\left(30 \mu \mathrm{g} \mathrm{ml}^{-1}\right)$ and colistin $\left(10 \mu \mathrm{g} \mathrm{ml}^{-1}\right)$. Insertional inactivation then occurred, resulting in the integration of the cloned suicide vector

Table 1. Oligonucleotides used in this study. SacI restriction sites introduced for cloning of PCR products are underlined

\begin{tabular}{|ll|}
\hline \multirow{2}{*}{ Designation } & \multicolumn{1}{c|}{ Sequence } \\
\hline$\Delta e s e B-1$ & 5'-GAG AGA GCT CTG ACT GAC TGA GCG ATA GCA TCA \\
& TGT CCG AC-3' \\
$\Delta e s e B-2$ & 5'-AGA GGA GCT CCG TGA TGT TGA TGT TGT GAT-3' \\
$\Delta e s e B-3$ & 5'-GAG AGG ATC CAT GAC TGT CAA TAC AGA CTA C-3' \\
$\Delta e s e B-4$ & 5'-AGA GCG CCG GCG GCG GAT ATT CTG GGC GAT \\
& GGA T-3' \\
$\Delta e s e C-1$ & 5'-GAG AGA GCT CTG ACT GAC TGA AGC AGG ATC ACG \\
& ATC CTA AG-3' \\
$\Delta e s e C-2$ & 5'-AGA GGA GCT CGC ATT GTC CTT ATC GAT CAG-3' \\
$\Delta e s e C-3$ & 5'-GAG AGA ATT CAT GGT GCG CCG CCA AGC CGC A-3' \\
$\Delta e s e C-4$ & 5'-AGA GCG CCG GCG GGC GAT ATT GGC GGC GAT \\
& GTT-3' \\
$\Delta e s e D-1$ & 5'-GAG AGA GCT CTG ACT GAC TGA TGA ATG AGC TGA \\
& TGG TTC AG-3' \\
$\Delta e s e D-2$ & 5'-AGA GGA GCT CTG CTG TTA ACG CCG TTG CTA-3' \\
$\Delta e s e D-3$ & 5'-GAG AGG ATC CAT GAC GAC TAT CGA CAG CGG CA-3' \\
$\Delta e s e D-4$ & 5'-AGA GCG CCG GCG GGA CAT GCG TAC GCT GCT \\
& GGC GAT A-3'
\end{tabular}


into the eseB, eseC, and eseD genes in the wild-type genome as described previously (Tan et al. 2005). Single strains retaining the mutant ese $B$, eseC, or eseD gene were selected as the EseB, EseC, and EseD mutants, respectively.

FK1051 was grown in Tripto-Soy broth (TSB, Eiken) at $30^{\circ} \mathrm{C}$. The Type III mutant mET1229 was grown in TSB supplemented with kanamycin $\left(50 \mu \mathrm{g} \mathrm{ml}^{-1}\right)$. EseB, EseC, and EseD mutants were grown in TSB supplemented with chloramphenicol $\left(30 \mu \mathrm{g} \mathrm{ml}^{-1}\right)$. Formalinkilled FK1051 was prepared as described previously (Clemens et al. 2004).

The influence of the incubation temperature on EseB, EseC, and EseD secretion was determined as follows: the wild-type strain and mET1229 were grown in TSB medium at $20,25,30$, and $37^{\circ} \mathrm{C}$ to an absorbance of light with a wavelength of $600 \mathrm{~nm}\left(A_{600}\right)=0.9$.

The influence of the $\mathrm{pH}$ in the culture media on EseBCD secretion was determined as described previously (Beuzon et al. 1999). The wild-type strain and mET1229 were grown in $\mathrm{pH} 7.4 \mathrm{TSB}$ medium at $25^{\circ} \mathrm{C}$ until an $A_{600}=0.6$, and then the cells were inoculated into fresh TSB media at pH 5.5, 6.5, 7.4, or 8.5 and incubated at $25^{\circ} \mathrm{C}$ for $24 \mathrm{~h}$.

J774 cells. J774 cells, a murine macrophage-like cell line derived from BALB/c mice, were obtained from the American Type Culture Collection. J774 cells were maintained in RPMI1640 (Sigma) supplemented with $10 \%$ FCS.

Infection of $\mathbf{J 7 7 4}$ cells with Edwardsiella tarda strains. A 24 -well tissue culture plate was inoculated with $7.5 \times 10^{4} \mathrm{~J} 774$ cells per well and incubated overnight at $37^{\circ} \mathrm{C}$ and under $5 \% \mathrm{CO}_{2}$. The cells were infected with either the wild-type E. tarda strain or the mET1229, EseB, EseC, and EseD mutants at a multiplicity of infection (moi) of 1 for $30 \mathrm{~min}$. Pre-warmed tissue culture medium containing $200 \mu \mathrm{g} \mathrm{ml} \mathrm{m}^{-1}$ gentamicin was then added. After $1.5 \mathrm{~h}$ incubation, the medium was removed, the cells were washed twice with PBS and new tissue culture medium was added. The J774 cells were incubated for $0,5,12$, or $22 \mathrm{~h}$ at $37^{\circ} \mathrm{C}$ and under $5 \% \mathrm{CO}_{2}$. At the end of each time period, the cells were washed twice with PBS, lysed with $1 \%$ Triton X-100 and cultured on plates to estimate the colony forming units (CFU) in the macrophages.

Preparation of secreted proteins. Secreted proteins in the culture supernatant were isolated using TCA precipitation. TCA was added to the culture supernatant to $10 \%$ and incubated on ice for $15 \mathrm{~min}$. After centrifugation at $15000 \times g$ for $15 \mathrm{~min}$, the precipitated proteins were washed 3 times with acetone and dried. The dried proteins were dissolved in PBS and the concentration was determined using the Bradford assay (BioRad).
Protein analysis. Secreted protein profiles were analyzed using sodium dodecylsulfate-polyacrylamide gel electrophoresis (SDS-PAGE) according to the method of Laemmli (1970). A $5 \mu \mathrm{g}$ sample was applied to $12.5 \%$ gel. Protein bands were visualized using Coomassie Brilliant Blue R-250 (CBB; Wako) or Silver Stain Kit II (Wako).

Amino acid sequencing. The proteins separated by SDS-PAGE were transferred to a polyvinylidene fluoride (PVDF) membrane (Millipore). After staining the PVDF membrane with CBB, protein bands in the membrane were excised. The amino acid sequence was determined using a G1005A Protein Sequencing System (Hewlett-Packard).

Labeling of acidified phagosomes with LysoTracker red DND-99. LysoTracker red DND-99 (Molecular Probes), an acidotropic dye, consists of a weak base conjugated to a red fluorophore and is used as a marker of phagosomal acidification and maturation (Toyooka et al. 2005). J774 cells were pretreated with LysoTracker (25 nM) in RPMI1640 for $2 \mathrm{~h}$ before infection. The cells were then infected with the wild-type strain or mET1229 at an moi of 20 for 30 min and pre-warmed tissue culture medium containing $200 \mu \mathrm{g} \mathrm{ml}^{-1}$ gentamicin and $25 \mathrm{nM}$ LysoTracker was added. After incubation for $1.5 \mathrm{~h}$, the medium was removed, washed twice with PBS, and tissue culture medium containing LysoTracker ( $25 \mathrm{nM}$ ) was added. The J774 cells were incubated for $1 \mathrm{~h}$ at $37^{\circ} \mathrm{C}$ and $<5 \% \mathrm{CO}_{2}$. At the end of time period, the cells were washed twice with PBS, fixed in $4 \%$ paraformaldehyde for 20 min, washed again with PBS, and treated with $\mathrm{NH}_{4} \mathrm{Cl}$. Then the cells were made permeable with $0.2 \%$ Triton X-100. Cover slips covered with the cells were incubated in anti-Edwardsiella tarda rabbit serum (1:640) for $1 \mathrm{~h}$ at $37^{\circ} \mathrm{C}$ and $<5 \% \mathrm{CO}_{2}$, washed with Tris-buffered saline Tween (TBS-T); and incubated with Alexa Fluor 488 chicken anti-rabbit IgG antibody (Molecular Probes) (1:100). The cover slips were mounted on glass slides and phagosomes containing bacteria were examined using a confocal laser scanning microscope system (LSM 510, Carl Zeiss). The percentage of acidic phagosomes were calculated as the ratio of the green bacteria to the total number of bacteria (total ca. 50 to 60 bacteria). The statistical analysis was performed using the 2-tailed $t$-test.

\section{RESULTS AND DISCUSSION}

\section{Identification of proteins secreted via the TTSS of Edwardsiella tarda}

The supernatant proteins of the wild-type strain and the Type III mutant (mET1229) are shown in Fig. 1A. The major 3 bands at the positions 55, 25, 


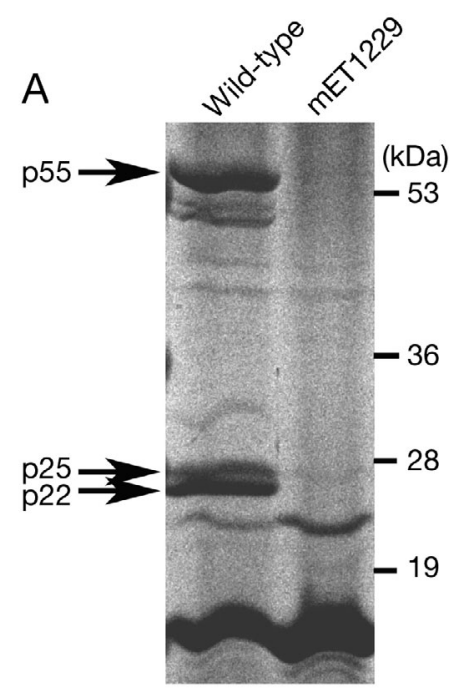

$\mathrm{B}$

$$
\begin{aligned}
& \text { EseB (theo.) } \\
& \text { p25 (sequenced) T'V'NT'DY'H'H'G' }
\end{aligned}
$$

Fig. 1. Edwardsiella tarda. Identification of proteins secreted through the Type III secretion system (TTSS) of E. tarda. (A) Secreted proteins from the wild-type strain or mET1229 were separated by SDS-PAGE and stained with Coomassie Brilliant Blue. (B) N-terminal amino acid sequence of the $25 \mathrm{kDa}$ protein was determined and compared to the predicted gene product of EseB [EseB (theoretical)]

and $22 \mathrm{kDa}$ were detected in the wild-type, but not in the mET1229 samples. The N-terminal amino acid sequence (10 residues) of the $25 \mathrm{kDa}$ protein was determined (Fig. 1B); however, the 55 and $22 \mathrm{kDa}$ sequences were not determined because they have an N-terminal block. A BLAST search shows that the $25 \mathrm{kDa}$ protein is similar to the predicted $\mathrm{N}$-terminal sequence of EseB, and has a sequence similarity to Salmonella SseB, that functions as a translocon (Srinivasa Rao et al. 2004). In Salmonella, a set of substrate proteins consisting of $\mathrm{SseB}, \mathrm{SseC}_{\text {, }}$ and $\mathrm{SseD}$ are secreted by the TTSS and these proteins are predominantly assembled into complexes on the bacterial cell surface to function as the translocon for the translocation of effector proteins such as SspH1 and $\mathrm{SspH} 2$ (Nikolaus et al. 2001). Since the EseB, EseC and EseD proteins of Edwardsiella tarda are previously reported to be the homologues of Salmonella SseB, SseC and SseD (Srinivasa Rao et al. 2004), we considered the 55 and $22 \mathrm{kDa}$ proteins to be EseC and EseD, respectively. To confirm that the 25, 55 and $22 \mathrm{kDa}$ proteins were $\mathrm{EseB}, \mathrm{EseC}$, and EseD, respectively, we constructed knockout mutants in the genes coding for EseB, EseC, and EseD in E. tarda

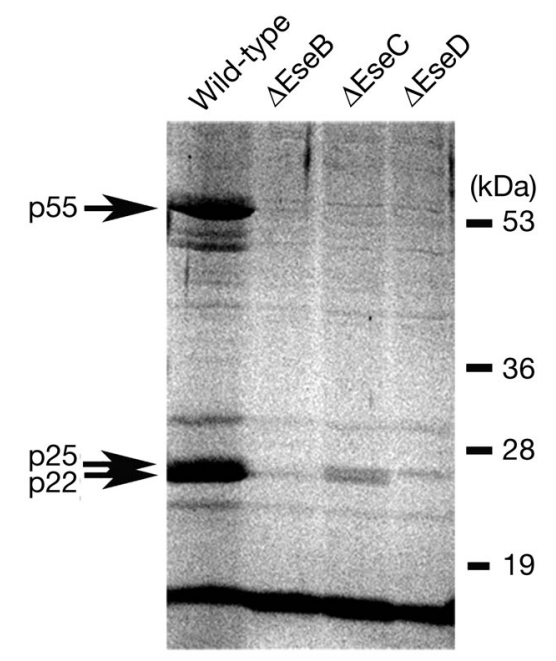

Fig. 2. Edwardsiella tarda. Secretion of eseB-, eseC- and ese $D$-deficient mutants. Secreted proteins from the wild-type strain (wild-type), ese $B$ - $(\Delta \mathrm{EseB})$, ese $C$ - $(\Delta \mathrm{EseC})$ and eseD$(\triangle$ EseD) deficient mutants were determined using SDS-PAGE and stained with Coomassie Brilliant Blue

(Fig. 2). As expected, the knockouts of EseB, EseC, and EseD resulted in the disappearance of the 25, 55, and $22 \mathrm{kDa}$ proteins, respectively. However, the knockout of the gene coding for EseB caused the disappearance of the $55 \mathrm{kDa}$ protein $(\mathrm{EseC})$ as well as the $25 \mathrm{kDa}$ protein (EseB) and the knockout of the gene coding for EseD resulted in the disappearance of the $55 \mathrm{kDa}$ protein (EseC) as well as the $22 \mathrm{kDa}$ protein (EseD). This suggests that the knockout of the ese $B$, ese $C$, or ese $D$ gene influences the secretion of the mutual genes. In Salmonella, similar observations are reported where the sseC mutant causes downregulation of the expression of $\mathrm{SseD}$ and the $s s e D$ mutant results in the down-regulation of $\mathrm{SseC}$ (Chakravortty et al. 2005). However, we cannot rule out the possibility that disappearance of the secretion of the $55 \mathrm{kDa}$ protein (EseC) may also be due to polar effects on the $25 \mathrm{kDa}$ protein (EseB) since the ese $C$ gene is located downstream of the ese $B$ gene (Tan et al. 2005), and in another report, the deletion mutant of $\Delta e s e B$ in a different strain did not affect the secretion of EseC and EseD (Zheng et al. 2007). On the other hand, the eseC gene is located upstream of the eseD gene (Tan et al. 2005); therefore, the observation of reduced secretion of the $55 \mathrm{kDa}$ protein (EseC) may not be due to polar effects on the $22 \mathrm{kDa}$ protein (EseD), but may be similar to the observation reported previously, where, in Salmonella, the sseD mutant results in the down-regulation of $\mathrm{SseC}$ (Chakravortty et al. 2005). 


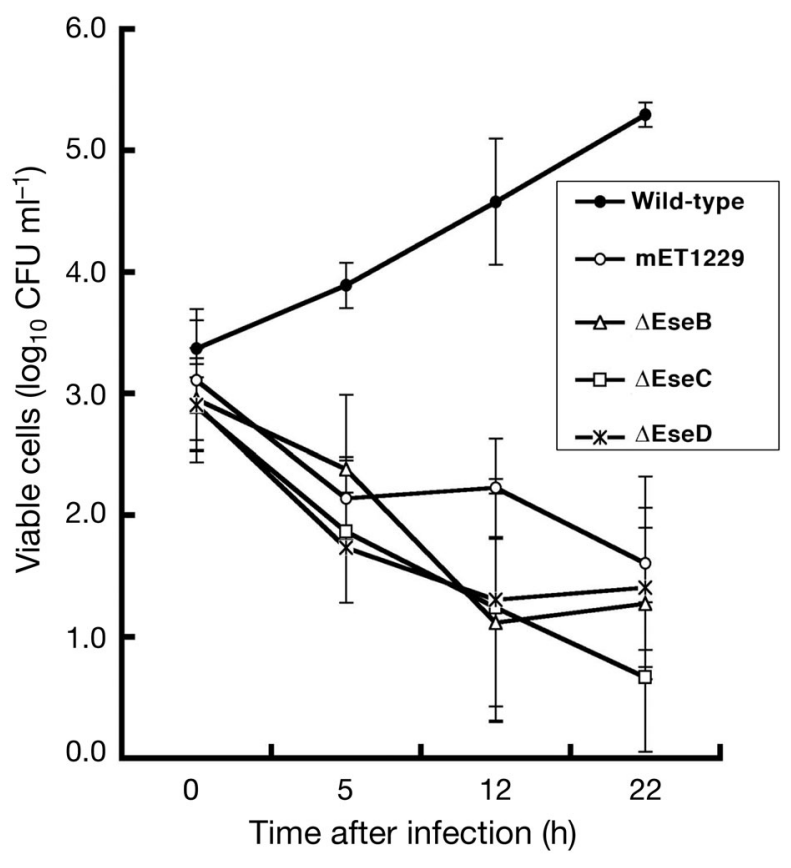

Fig. 3. Edwardsiella tarda. Intracellular growth of wild-type $E$. tarda, mET1229, $\Delta$ EseB, $\Delta$ EseC, and $\Delta$ EseD mutants in J774 macrophages. Mono-layers of $\mathrm{J} 774$ cells were infected with $7.5 \times 10^{4}$ bacteria, incubated for the indicated periods (time after infection), then treated with $200 \mathrm{\mu g} \mathrm{ml}^{-1}$ gentamicin for $1.5 \mathrm{~h}$ and lysed with $1 \%$ Triton X-100. Numbers of viable bacteria are shown as mean \pm SD of 3 culture counts

\section{Requirement of EseB, EseC, and EseD proteins for intracellular replication of Edwardsiella tarda}

The average number of viable wild-type cells replicating in J774 cells increased 5 to $22 \mathrm{~h}$ after infection, while the EseB, EseC, and EseD mutants decreased in a time-dependent manner. Most of the mutants enter-

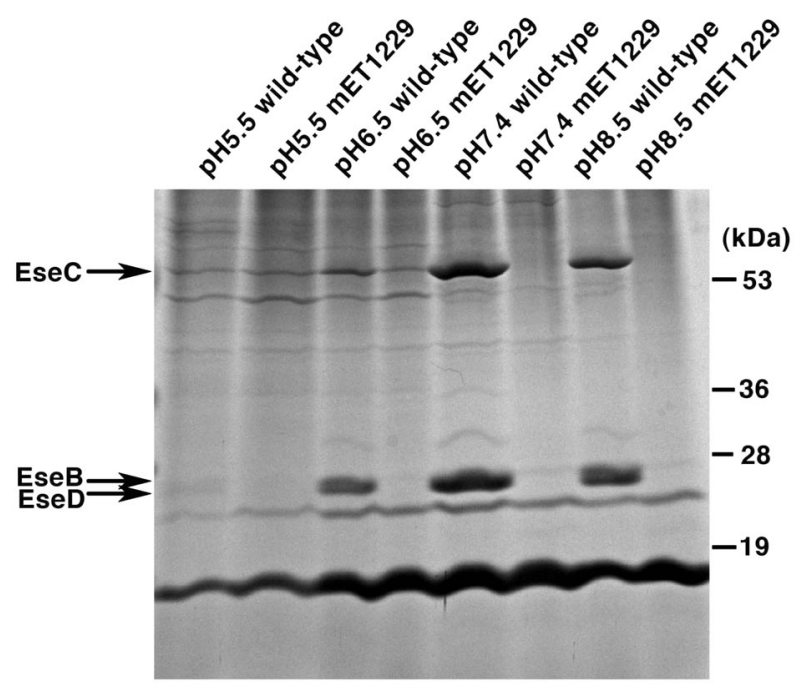

Fig. 4. Edwardsiella tarda. Influence of $\mathrm{pH}$ shift on EseBCD protein secretion in the wild-type strain and mET1229 mutant. Both were cultured in TSB and a $\mathrm{pH}$ shift was performed by replacing the culture media with fresh TSB media at $\mathrm{pH} 5.5,6.5,7.4$, or 8.5 , followed by incubation at $25^{\circ} \mathrm{C}$ for $24 \mathrm{~h}$. Secreted proteins $(5 \mu \mathrm{g})$ were identified using SDS-PAGE and stained with Coomassie Brilliant Blue R-250

ing J774 cells were no longer viable $22 \mathrm{~h}$ after infection (Fig. 3). This suggests that the EseB, EseC, and EseD proteins are essential for intracellular survival of Edwardsiella tarda in murine macrophages. This was similar to observations in Salmonella, i.e. the growth of strains carrying mutations in $s s e B$ or sseC within murine macrophages was severely decreased (Hensel et al. 1998). Tan et al. (2005) reported that intracellular growth of the eseB, eseC, and eseD insertional mutants in fish phagocytes decreased moderately, compared to

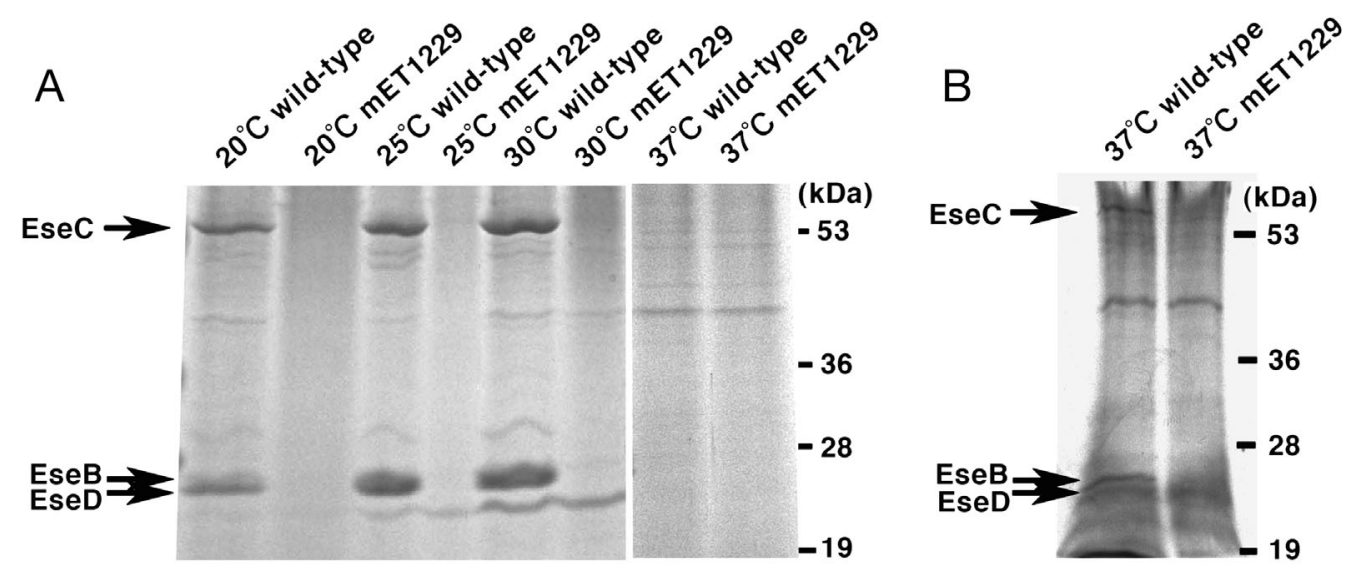

Fig. 5. Edwardsiella tarda. Influence of incubation temperature on EseBCD protein secretion. Cultures of the wild-type strain and mET1229 mutant were grown at $20,25,30$, or $37^{\circ} \mathrm{C}$. Secreted proteins were separated using SDS-PAGE and stained with (A) Coomassie Brilliant Blue R-250 or (B) silver staining 


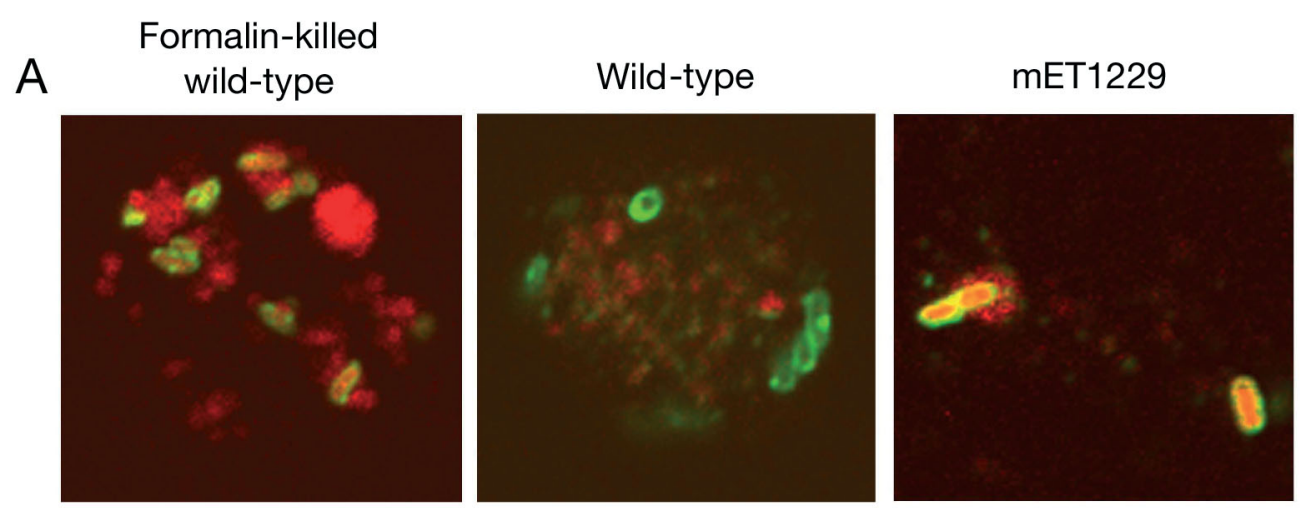

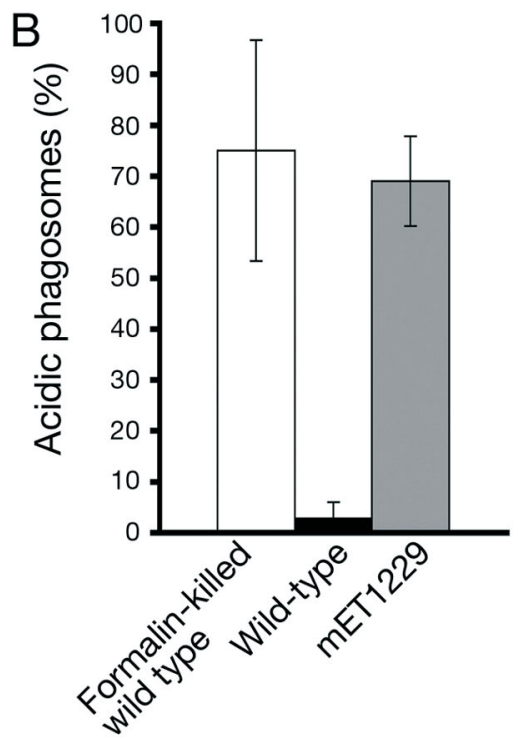

the wild-type strain. However, we found that $5 \mathrm{~h}$ after infection, intracellular growth of the eseB, eseC, and ese $D$ mutants in murine macrophages decreased considerably, compared to the wild-type strain. This difference between the obeservations of Tan et al. (2005) and our data may be due to differences between fish phagocytes and murine macrophages.

\section{Effect of culture conditions on the secretion of the EseBCD proteins}

We investigated whether secretion of the EseBCD proteins was influenced by culturing bacterial cells in media at different pHs. We show in Fig. 4 that EseBCD proteins were secreted when the wild-type strain was cultured in media at neutral $(\mathrm{pH} 7.4)$ or alkaline ( $\mathrm{pH}$ 8.5) $\mathrm{pH}$, while the secretion of these proteins was faint when the wild-type strain was cultured in media at an acidic $\mathrm{pH}$ ( $\mathrm{pH}$ 5.5). This was different for the Sse-
Fig. 6. Edwardsiella tarda. Acidity of phagosomes in J774 cells infected with the formalin-killed wild-type strain, the wild-type strain or mET1229 mutant was determined by staining the phagosomes with LysoTracker Red DND-99. J774 cells were infected with the formalin-killed wild-type strain, the wild-type strain or the mET1229 mutant and observed using a laser confocal microscope $1 \mathrm{~h}$ after infection. A representative photograph of each strain is shown (A). (B) Percentage (mean $\pm \mathrm{SD}$ ) of acidic phagosomes. Differences between the formalin-killed wild-type and wild-type strains $(p<0.002)$ and between the wild-type strain and the mET1229 mutant $(p<0.001)$ were significant

BCD proteins found in Salmonella (Nikolaus et al. 2001), where the SseBCD proteins were most secreted when bacterial cells were cultured in media at acidic $\mathrm{pH}$ ( $\mathrm{pH}$ 5.0). This suggests that after ingestion by macrophages Edwardsiella tarda prevents acidification of the phagosomes in order to allow secretion of the EseBCD proteins through the TTSS.

Srinivasa Rao et al. (2004) previously reported that the EseB and EseD protein production was markedly reduced at $37^{\circ} \mathrm{C}$ incubation but was observed by 2dimensional gel electrophoresis (2-DE) followed by silver staining. Similarly in our study, the EseBCD proteins were secreted at highest levels when the wild-type strain was incubated at 25 to $30^{\circ} \mathrm{C}$, while secretion of these proteins was markedly reduced at $37^{\circ} \mathrm{C}$ (Fig. 5A), as detected by SDS-PAGE followed by silver staining (Fig. 5B), which coincides with the observation by Srinivasa Rao et al. (2004). This temperature dependency of translocon protein secretion will be of importance in clarifying the infection mechanism of Edwardsiella tarda in cultured fishes, which are usually reared in water with temperatures $<30^{\circ} \mathrm{C}$. Further investigations are required to reveal the relationship between fish virulence, or resistance of fish macrophages, and secretion of the translocon proteins. 


\section{pH of phagosomes after Edwardsiella tarda infection}

J774 cells infected with the formalin-killed wild-type strain, wild-type strain or mET1229 mutant were stained using the LysoTracker (Fig. 6). The majority of phagosomes in the J774 cells phagocytosing the formalin-killed wild-type strain or mET1229 colocalized with red acidic particles $1 \mathrm{~h}$ after infection. In contrast, phagosomes with the wild-type strain did not colocalize with acidic particles (Fig. 6). The differences between the formalin-killed wild-type and wild-type strains and between the wild-type strain and mET1229 were significant ( $p<0.002$ and $p<0.001$, respectively). This suggests that unidentified effector proteins through the TTSS may be secreted from the wild-type strain to prevent fusion of acidic particles with the phagosomes, resulting in the neutralization of the phagosomes. We speculate that neutralization of phagosomes is a prerequisite for the efficient secretion of the EseBCD translocon proteins that are essential for the successive secretion of unidentified effector proteins. Further investigation in identifying these unidentified effector proteins may provide important insights into the mechanism initiating intracellular replication of Edwardsiella tarda in macrophages.

Acknowledgements. This work was supported by 2 Grantsin-Aid for Scientific Research (Nos.18580184 and 18075) from the Ministry of Education, Science, Sports and Culture of Japan and the Ministry of Agriculture, Forestry and Fisheries of Japan, respectively.

\section{LITERATURE CITED}

Ainsworth AJ, Chen DX (1990) Differences in the phagocytosis of four bacteria by channel catfish neutrophils. Dev Comp Immunol 14:201-209

Beuzon CR, Banks G, Deiwick J, Hensel M, Holden DW (1999) pH-dependent secretion of SseB, a product of the SPI-2 type III secretion system of Salmonella typhimurium. Mol Microbiol 33:806-816

> Chakravortty D, Rohde M, Jager L, Deiwick J, Hensel M (2005) Formation of a novel surface structure encoded by Salmonella Pathogenicity Island 2. EMBO J 24:2043-2052

- Clemens DL, Lee BY, Horwitz MA (2004) Virulent and avirulent strains of Francisella tularensis prevent acidification and maturation of their phagosomes and escape into the cytoplasm in human macrophages. Infect Immun 72: $3204-3217$

Ghosh P (2004) Process of protein transport by the type III secretion system. Microbiol Mol Biol Rev 68:771-795

Hensel M, Shea JE, Waterman SR, Mundy R and others (1998) Genes encoding putative effector proteins of the type III secretion system of Salmonella pathogenicity island 2 are required for bacterial virulence and proliferation in macrophages. Mol Microbiol 30:163-174

Hirono I, Tange N, Aoki T (1997) Iron-regulated haemolysin gene from Edwardsiella tarda. Mol Microbiol 24:851-856
Iida T, Wakabayashi H (1993) Resistance of Edwardsiella tarda to opsonophagocytosis of eel neutrophils. Fish Pathol 28:191-192

> Janda JM, Abbott SL (1993) Infections associated with the genus Edwardsiella: the role of Edwardsiella tarda in human disease. Clin Infect Dis 17:742-748

$>$ Laemmli UK (1970) Cleavage of structural proteins during the assembly of the head of bacteriophage T4. Nature 227:680-685

Muroga K (2001) Viral and bacterial diseases of marine fish and shellfish in Japanese hatcheries. Aquaculture 202: $23-44$

Nikolaus T, Deiwick J, Rappl C, Freeman JA, Schroder W, Miller SI, Hensel M (2001) SseBCD proteins are secreted by the type III secretion system of Salmonella pathogenicity island 2 and function as a translocon. J Bacteriol 183:6036-6045

Okuda J, Nakai T, Chang PS, Oh T, Nishino T, Koitabashi T, Nishibuchi M (2001) The toxR gene of Vibrio (Listonella) anguillarum controls expression of the major outer membrane proteins but not virulence in a natural host model. Infect Immun 69:6091-6101

> Okuda J, Arikawa Y, Takeuchi Y, Mahmoud MM and others (2006) Intracellular replication of Edwardsiella tarda in murine macrophage is dependent on the type III secretion system and induces an up-regulation of antiapoptotic NF-кB target genes protecting the macrophage from staurosporine-induced apoptosis. Microb Pathog 41:226-240

Plumb JA (1999) Edwardsiella septicemias. In: Woo PTK, Bruno DW (eds) Fish diseases and disorders. CABI Publishing, London, p 479-521

Sakazaki R (2001) Genus XI. Edwarsiella Ewing and McWhorter 1965, 37 ${ }^{\mathrm{AL}}$. In: Brenner DJ, Krieg NR, Staley JT, Garrity GM (eds) Bergey's manual of systematic bacteriology, 2nd edn, Vol. 2. Springer, New York, p 657-661

Srinivasa Rao PS, Lim TM, Leung KY (2001) Opsonized virulent Edwardsiella tarda strains are able to adhere to and survive and replicate within fish phagocytes but fail to stimulate reactive oxygen intermediates. Infect Immun 69:5689-5697

Srinivasa Rao PS, Lim TM, Leung KY (2003) Functional genomics approach to the identification of virulence genes involved in Edwardsiella tarda pathogenesis. Infect Immun 71:1343-1351

Srinivasa Rao PS, Yamada Y, Tan YP, Leung KY (2004) Use of proteomics to identify novel virulence determinants that are required for Edwardsiella tarda pathogenesis. Mol Microbiol 53:573-586

Strauss EJ, Ghori N, Falkow S (1997) An Edwardsiella tarda strain containing a mutation in a gene with homology to shlB and $h p m B$ is defective for entry into epithelial cells in culture. Infect Immun 65:3924-3932

Tan YP, Zheng J, Tung SL, Rosenshine I, Leung KY (2005) Role of type III secretion in Edwardsiella tarda virulence. Microbiology 151:2301-2313

> Toyooka K, Takai S, Kirikae T (2005) Rhodococcus equi can survive a phagolysosomal environment in macrophages by suppressing acidification of the phagolysosome. J Med Microbiol 54:1007-1015

Ullah MA, Arai T (1983) Pathological activities of the naturally occurring strains of Edwardsiella tarda. Fish Pathol 18:65-70

Zheng J, Li N, Tan YP, Sivaraman J, Mok YK, Mo ZL, Leung $\mathrm{KY}$ (2007) EscC is a chaperone for the Edwardsiella tarda type III secretion system putative translocon components EseB and EseD. Microbiology 153:1953-1962

Submitted: May 15, 2007; Accepted: January 19, 2009

Proofs received from author(s): March 17, 2009 